\title{
RISK MANAGEMENT PADA INDUSTRI OTOMOTIF
}

Angelita Nauli Panggabean - 2301950881 - LB21

E-Business Strategy and Implementation

\begin{abstract}
Abstrak
Kebutuhan pasar yang semakin tinggi dan persaingan yang semakin ketat, menuntut perusahaan untuk selalu berusaha mengembangkan perusahaannya dengan menghadirkan produk baru di pasar. Dari sinilah, dapat dilihat bahwa bahwa manajemen risiko proyek dalam menghadirkan produk baru, sangatlah penting dan perlu diberi perhatian. Jika risiko proyek tidak dikendalikan dengan baik, maka akan menyebabkan ganguan dalam proses proyek itu sendiri. Tujuan dari karya tulis ini adalah untuk mengetahui pentingnya penerapan manajemen risiko pada industri otomotif. Metode yang digunakan penulis adalah mengumpulkan dan mempelajari jurnal-jurnal dari internet untuk mencapai kesimpulan. Kesimpulannya, bahwa manajemen risiko merupakan alat manajemen penting bagi para manajer proyek dalam meningkatkan keberhasilan proyek.
\end{abstract}

Kata Kunci: Risk Management, Industri Otomotif

\section{Pendahuluan}

Di era globalisasi ini dimana persaingan dalam dunia bisnis semakin ketat (Hida Syahchari \& Amsal Sahban, 2019), menuntut para perusahaan untuk menjaga kepercayaan para stakeholder terhadap perusahaan. Perusahaan diharapkan dapat mengungkapkan dan memberikan informasi terkait kinerja perusahaan untuk lebih transparan (Dwiharto, 2020). Namun, nyatanya banyak informasi yang tidak lengkap disertai dengan tingkat ketidakpastian, dimana ketidakpastian ini menyebabkan risiko pada perusahaan itu sendiri (Mirboroon \& Razavi, 2020). Dalam industri otomotif, untuk mencapai kesuksesan industri adalah dengan pemanfaatan peluang dan sumber daya yang ada untuk mengembangkan dan berinovasi terhadap produk dan layanan yang dapat memenuhi kebutuhan pasar. Elemen penting dalam memanfaatkan peluang yang tersedia adalah membuat keputusan yang idealnya harus dilakukan berdasarkan informasi yang lengkap dengan tingkat kepastian yang tinggi mengenai output (Mirboroon \& Razavi, 2020). Kenyataanya, sebagian besar keputusan yang dibuat dengan informasi yang tidak lengkap akan mengakibatkan risiko dalam suatu proyek. Dengan begitu, proyek yang bercampur dengan ketidakpastian dan ketidaklengkapan akan selalu menjadi bagian dari manajemen proyek (Mirboroon \& Razavi, 2020). Risiko tersebut bergantung pada berbagai faktor yang meliputi jenis proyek, produk dari supplier, waktu proyek, orang-orang yang terkait, serta faktor internal dan eksternal lainnya. Risiko pada protek juga dapat mencakup risko yang berbeda, antara lain eksekutif, keuangan, ekonomi, dan risiko lingkungan. Berdasarkan (Mirboroon \& Razavi, 2020) pada umumnya, risiko proyek diklasifikasikan sebagai risko terkait pelaksaan, risiko waktu, risiko biaya, akumulasi 
risiko, risiko linkungan dan bencana. Dengan merancang sistem informasi manajemen risiko pada proyek akan secara signifikan membantu dalam mengindentifikasi risiko. Luasnya industri otomotif, indikator manajamen biaya, pembelian, kualitas dan jumlah orang yang bekerja telah menjadi fokus para ahli pengendalian risiko proyek, dengan tujuan untuk mengetahui seberapa tinggi risiko mempengaruhi kualitas perencanaan dan keberhasilan suatu proyek. Jika risiko proyek tidak dikendalikan dengan baik, maka akan menyebabkan ganguan dalam proses proyek tersebut sehingga akan juga menyebabkan masalah pada perusahaan yang lebih buruk. Masalah tersebut tentunya adalah masalah tidak biasa, mengingat industri otomotif merupakan industri dengan modal tinggi. Selain meningkatkan keberhasilan proyek, manajemen risiko juga dapat menjaga sumber daya manusia dan kegiatan industri otomotif dengn baik. Manajemen risiko membantu para manajer membuat keputusan menjadi lebih terarah (Mirboroon \& Razavi, 2020). (Pimchangthong \& Boonjing, 2017) juga menyebutkan, bahwa manajemen risiko merupakan salah satu faktor penting yang mempengaruhi keberhasilam proyek.

\section{Tinjauan Pustaka}

\section{Risk Management}

Dalam menghadapi pasar, manajemen risiko yang efektif merupakan komponen penting dari setiap strategi manajemen yang unggul (Tupa et al., 2017). Risk management atau manajemen risiko adalah proses mengindentifikasi, menilai, menganalisis, dan bertindak atas berbagai ketidakpastian yang dapat menimbulkan masalah atau kegagalan (Yoga Irsyadillah \& Dadang, 2020). (Tupa et al., 2017) juga mendefinisikan risiko manajemen sebagai cara yang komperhensif dan sistematis untuk mengidentifikasi, menganalisis, dan menaggapi risiko untuk mencapai tujuan proyek. Berdasarkan (Pimchangthong \& Boonjing, 2017), manajemen risiko merupakan alat manajemen paling penting yang dapat digunakan manajer proyek untuk meningkatkan kemungkinan keberhasilan proyek. (Mirboroon \& Razavi, 2020), juga menyebutkan bahwa manajemen risiko sangat penting karena memberikan manajer proyek pandangan ke dapan, baik itu ancaman maupun peluang untuk meningkatkan keberhasilan suatu proyek. Dengan kata lain, manajemen risiko dapat membantu organisasi untuk memahami apa risikonya, siapa risikonya, apa control saat ini, dan penilaian yang perlu dibuat tentang apakah kontrol tindakan tersebut memadai atau tidak. Jika tidak memadai, maka diperlukan tindakan untuk mengelola tingkat risiko yang tepat dan dapat diterima (Tupa et al., 2017). Namun, manajemen risiko tidak selalu diterapkan oleh manajer proyek. Hal ini disebabkan oleh alasan keuangan dan juga penerapan manajemen risiko yang tidak konsisten dalam praktiknya (Pimchangthong \& Boonjing, 2017). Manajemen risiko proyek merupakan sebuah seni dan ilmu yang digunakan untuk mengidentifikasi, menganalisis, dan menanggapi risiko sepanjang umur proyek dalam mencapai tujuan proyek (Pimchangthong \& Boonjing, 2017). Selain itu, menurut (Yushita, 2008), manajemen risiko diartikan sebagai rangkaian prosedur dan metodologi yang berguna untuk mengindentifikasi, mengendalikan, dan mengukur risko yang muncul dari suatu kegiatan. Berdasarkan penelitian Pimchangton dan 
Boonjing (2017), menunjukkan bahwa manajamen risiko yang buruk memungkinkan terjadinya penyebab masalah dan kegagalan suatu proyek. Dengan kata lain, manajemen risiko ini merupakan proses yang sangat penting untuk keberhasilan sebuah proyek. Dalam penelitiannya pun menyebutkan bahwa terdapat enam proses yang melibatkan manajemen risiko, antara lain: perencanaan manajemen risiko, identifikasi risiko, analisis risiko kualitatif, analisis risiko kuantitatif, perencanaan respons risiko, serta pemantauan dan pengendalian risiko.

\section{Metodologi}

Karya tulis ini melakukan pencarian beberapa jurnal yang terkait dengan manajemen risiko pada industi otomotif. Tahapan selanjutnya adalah membaca dan mempelajari jurnal-jurnal tersebut lalu dilakukan pengecekkan relevansi artikel untuk melengkapi informasi yang dibutuhkan. Setelah itu, informasi dari jurnal yang terpilih dikumpulkan dan digunakan untuk mencapai kesimpulan.

\section{Kesimpulan}

Melihat kebutuhan pasar dan daya Tarik pelanggan, industri otomotif selalu berusaha untuk menghadirkan produk baru yang sesuai dengan pasar. Dalam menghadirkan produk baru, industri otomotif berarti memiliki sebuah proyek. Proyek ini akan berjalan dengan lancar jika manajemen risiko proyek di industri mobil diberi perhatian khusus. Manajemen risiko sangat penting karena memberikan manajer proyek pandangan ke depan, baik itu ancaman maupun peluang untuk meningkatkan keberhasilan proyek. Kesimpulannya, penerapan manajemen risiko diperlukan untuk keberhasilan suatu proyek pada industri otomotif.

\section{Reference:}

Dwiharto, P. (2020). Factors Affecting The Area of Risk Management Disclosures. Business and Accounting Research (IJEBAR) Peer Reviewed-International Journal, 4(4).

Hida Syahchari, D., \& Amsal Sahban, M. (2019). The Impact of Intellectual Capital and Knowledge Management on Competitive Advantage. In International Journal of Innovation, Creativity and Change. www.ijicc.net (Vol. 10, Issue 8). www.ijicc.net

Mirboroon, L., \& Razavi, H. (2020). A Case Study of Risk Management of Automotive Industry Projects Using RFMEA Method. Mapta Journal of Mechanical and Industrial Engineering (MJMIE), 4(1), 42-50. https://doi.org/10.33544/mjmie.v4i1.132

Pimchangthong, D., \& Boonjing, V. (2017). Effects of Risk Management Practices on IT Project Success. Management and Production Engineering Review, 8(1), 30-37. https://doi.org/10.1515/mper-2017-0004 
Tupa, J., Simota, J., \& Steiner, F. (2017). Aspects of Risk Management Implementation for Industry 4.0. Procedia Manufacturing, 11, 1223-1230.

https://doi.org/10.1016/j.promfg.2017.07.248

Yoga Irsyadillah, N., \& Dadang, S. (2020). A Literature Review of Supply Chain Risk Managament in Automotive Industry. Journal of Modern Manufacturing Systems and Technology, 4(2), 12-22. https://doi.org/10.15282/jmmst.v4i2.5020

Yushita, A. N. (2008). Implementasi Risk Managament pada Industri Perbankan Nasional. Jurnal Pendidikan Akuntansi Indonesia, 6(1), 75-86. 